\title{
THE IMPACT OF SUPPLY CHAIN STRATEGY ON THE FINANCIAL PERFORMANCE: A CASE STUDY OF A MANUFACTURING COMPANY at KHARTOUM STATE
}

\section{Lina Mohamed Ahmed baabaker}

Department of business administration, Business Studies Section -Elbyan Science \& Technology College, Khartoum, Sudan

\section{Nuseiba Azzam Ibrahim}

Department of business administration, College of Business Studies Sudan University of Science \& Technology, Khartoum, Sudan

\section{Hawaa Abdallah Belal Saadallah}

Assistant Professor, Faculty of Community, Department of Humanitarians and Management Science, Jouf University,

\section{Mushtaha Alfadil Yahia Juma}

Department of business administration, Business Studies Section -University of Bahari

\section{Doi: 10.21608/ajsr.2021.177516}

baabaker, Lina Mohamed Ahmed \& Nuseiba Azzam Ibrahim \& Saadallah Hawaa Abdallah Belal \& Juma, Mushtaha Alfadil Yahia (2021). THE IMPACT OF SUPPLY CHAIN STRATEGY ON THE FINANCIAL PERFORMANCE: A CASE STUDY OF A MANUFACTURING COMPANY at KHARTOUM STATE. The Arab Journal of Scientific Research, AIESA, Vol. 5 Issue 5. 


\section{ABSTRACT}

Purpose of this paper: The aim of this paper is to propose a systems view to link supply chain (SC) strategy to a company's financial performance by developing a scenario approach. The paper applies five scenarios under differing financial performance contexts to analyse the relationship between supply chain performance and the overall financial performance.

Design/methodology/approach: An integrated supply chain performance measurement system was created and implemented to demonstrate and utilise the relationship between SC performance metrics and the financial performance metrics. A scenario analysis approach was undertaken using five main alternative scenarios in order to explore how this procedure could be applied with regard to various possible financial results. A case study of a manufacturing company was conducted and analysed to illustrate the applicability of the research procedure.

Findings: The results reflected the improvement in the efficiency and the effectiveness of SC strategy in connection with the company's short-term strategic financial objectives. The analysis showed that any improvement in the SC operations' performance will lead to better supply chain management (SCM), and consequently enhance the company's overall financial performance. An improvement in SC performance as well as financial performance has been shown for the three conditions (optimistic, normal and pessimistic) following the proposed procedure.

Value: A systems view is introduced to integrate SC strategy and the company's overall financial strategy under different possible scenarios based on the systems view problem-solving model. Five main alternative scenarios are defined given the related targeted financial outcomes and their corresponding present paths (managing SC costs, increasing SC agility,

\section{$\varepsilon$.}


improving SC reliability, increasing SC responsiveness and managing SC assets).

The system can be operated in two directions given two possible loops. A company can formulate SC strategy to achieve targeted strategic financial objectives or it can start with an unsatisfactory financial performance and then formulate the corresponding SC strategy to enhance it.

Research limitations/implications: The research study makes an original contribution in the direction of linking SC strategy to a company's financial strategy through focusing on studying the relationships between SCM practices and financial performance improvements. Further research should investigate and compare the results from several companies in different sectors of manufacturers in different locations.

Practical implications: The paper follows a systems view which can help in determining the most appropriate SC strategy with regard to targeted financial objectives. This paper benefits from data extracted from a manufacturing company by evaluating the applicability of the model developed under a different set of scenarios.

\section{INTRODUCTION}

Supply chain management (SCM) has been documented to be positively associated with enhanced competitiveness and improved company performance (Li et al., 2006). Limited research has been proposed to investigate links between supply chain (SC) performance and improved financial performance (Wagner et al., 2012). This paper aims at studying the relationship between supply chain performance and the overall financial performance. In this essence, the paper further develops from the work considered in Elgazzar et al. (2012b) by proposing a scenario approach linking SC performance to 
financial performance. This work also demonstrates the practical applicability of the proposed scenarios through conducting a case study of a manufacturing company.

\section{LITERATURE REVIEW}

Financial performance measures are governed by rules and guidelines which make them a simple and clear source of useful information about financial outcomes and the internal operations shown in the financial statements (Zuriekat et al., 2011). However, relying on traditional financial methods and techniques alone to measure company performance is no longer the norm in large organisations (Basu, 2001).

Although most companies realise the importance of combining financial and non-financial performance measures, they have failed to represent them in a balanced framework (Gunasekaran et al., 2004). Developing an integrated performance measurement system is critical to achieve successful implementation of SCM practices (Cagnazzo et al., 2010). A limited number of studies have been conducted to demonstrate the potential impact of managing SC day-to-day practices on improving a company's financial performance (Gunasekaran et al., 2004; Presutti Jr. and Mawhinney, 2007; Woei, 2008; Kremers, 2010; Wisner, 2011; Wagner et al., 2012). Previous frameworks proposed in this area had a limited impact on enhancing an organisation's performance due to the inability to capture the critical link between SC performance and overall business performance in a way that covers all business dimensions and incorporates different levels of decision making (Camerinelli and Cantu', 2006; Toyli et al., 2008; Prajogo et al., 2016).

This consequently leads to the need for an applied methodology linking supply chain strategy to the company's financial performance. Case-based studies to analyse the impact of 
managing SC operations' performance on enhancing a company's overall financial performance are worthy of investigation.

\section{THE RESEARCH FRAMEWORK}

Elgazzar et al. (2012b) introduced a scenario analysis approach to link SC strategy to a company's financial performance. The financial performance was evaluated and analysed in terms of profitability and operating efficiency through assessing the contribution of each financial performance driver (revenue, cost and assets). Three different paths were identified to achieve the short-term strategic financial objectives, namely: increasing revenue, managing costs and improving asset utilisation. The appropriate path is selected through assessing the contribution of each financial performance driver to the company's profitability and/or operating efficiency. To correspond to the different possible paths, five main SC performance alternative scenarios (managing SC costs, increasing SC agility, improving SC reliability, increasing $\mathrm{SC}$ responsiveness and managing $\mathrm{SC}$ assets) were introduced based on the supply chain operation reference (SCOR) model performance metrics.

In this paper, a systems view of the scenarios is introduced to demonstrate the way in which SC strategy and the company's overall financial strategy can be integrated under different possible scenarios based on the systems view problem-solving model developed by Mitroff et al. (1974). Based on the system view of the scenarios, five main alternative scenarios are defined given the related targeted financial outcomes and their corresponding present paths. Both scenario one (managing SC costs) and scenario two (increasing SC agility) are relevant when the company's short-term strategic financial objective is to increase its profitability and the analysis of financial performance results highlights cost as the financial driver that most requires attention. Both scenario three (improving SC 
reliability) and scenario four (increasing SC responsiveness) are relevant when the analysis of financial performance results highlights revenue as the financial driver that most requires attention. Scenario five (managing SC assets) is relevant when the company's short-term strategic financial objective is to improve its efficiency and the analysis of financial performance results highlights assets as the financial driver that most requires attention. In addition, the analysis of SC performance indicates that SC processes to which asset management measures correspond register the poorest performance among all SC processes.

The system can be operated in two directions given two possible loops: (II, III, IV and I) and (I, II, III and IV). The systems view of the scenarios reflects the integration between SC strategy and the company's overall financial strategy. A company can formulate SC strategy to achieve targeted strategic financial objectives or it can start with an unsatisfactory financial performance and then formulate the corresponding SC strategy to enhance it.

The first direction starts with five main conceptual alternative scenarios (II). Then, a scientific model is formed to determine the relevant scenario that will be modelled and implemented (III). At this stage, the focus area for enhancing the financial performance is identified through assessing the contribution of each financial performance driver (revenue, cost and asset) and tracing their related SC operations. Then, SC operations that need improvement and their corresponding performance measures can be identified, and the relevant scenario is determined (managing SC costs, increasing SC agility, improving SC reliability, increasing SC responsiveness or managing SC assets). Consequently, the appropriate SC strategy is formulated (IV) and implemented to achieve the targeted financial outcomes (I). As illustrated in fig. 1, the second 
direction starts with an inappropriate financial performance result (I). In this case, the relevant scenario is constructed theoretically based on the recognition of a real problem situation (II). Once the relevant scenario is identified, the scientific model can be formed through tracing the source of poor performance in terms of relevant SC operations and then the corresponding SC performance measures can be determined based on the SCOR model standard performance metrics (III). Finally, the appropriate SC strategy is formulated to improve the performance of relevant SC operations, and consequently enhance financial performance results (IV).

According to the proposed system, first, the contribution of each financial performance driver is evaluated in order to determine the priorities of financial performance (increasing profitability and/or improving efficiency). Then, the SCOR FAHP technique developed by Elgazzar et al. (2010) is utilised to assess the SC performance. The weighted rates (WR) of all SC performance measures are calculated and aggregated throughout the hierarchy of the SC in order to determine the company's SC index (SCI). SCI traces the source of poor performance in terms of the relevant SC operations that need improvement and consequently identifying the corresponding SC performance measurement category (reliability (RL), responsiveness (RS), agility (AG), cost (CO) and asset management (AM)). Finally, based on the relative weights of $\mathrm{SC}$ performance measures and the priorities of financial performance factors, the company's new SC strategy for the new accounting period is formulated with respect to the relevant alternative scenario in order to achieve the short-term strategic financial objective (targeted outcome) through adopting the appropriate present path (increasing revenue, managing cost or improving asset utilisation). 


\begin{tabular}{|c|c|c|c|}
\hline Alternative scenarios & & Present paths & $\begin{array}{l}\text { Possible } \\
\text { outcomes }\end{array}$ \\
\hline $\begin{array}{lr}\text { SC } & \text { performance } \\
\text { metrics } & \\
\text { (SCOR } & \text { FAHP } \\
\text { technique) } & \\
\end{array}$ & ळે & $\begin{array}{l}\text { Financial } \\
\text { performance } \\
\text { drivers }\end{array}$ & $\begin{array}{l}\text { Financial } \\
\text { performance } \\
\text { metrics }\end{array}$ \\
\hline $\begin{array}{c}\sum \text { Improving } \\
\sum \text { Increasing } \mathrm{SC} .\end{array}$ & & Revenue & $\begin{array}{l}\text { Profitability \& } \\
\text { Efficiency } \\
\text { factor } \\
\end{array}$ \\
\hline$\sum$ & & Cost & $\begin{array}{l}\text { Profitability } \\
\text { factor }\end{array}$ \\
\hline$\Sigma$ & & Assets & $\begin{array}{l}\text { Efficiency } \\
\text { factor }\end{array}$ \\
\hline
\end{tabular}

Figure 2: The applied framework of the SCPMS (Developed from: Elgazzar, 2013)

A Supply Chain Financial Link Index (SCFLI) is calculated before and after implementing the new SC strategy to test the extent to which SC processes' performance is linked to the company's financial strategic objectives. The applied framework of the research method is presented in fig. 2. To demonstrate the applicability of SCPMS, a case study of a manufacturing company is presented and analysed in the next section. The data was collected for one year (referred to it in the text as period 1).

\section{CASE STUDY}

\subsection{Evaluating SC operations' performance}

The SCOR FAHP was implemented to evaluate SC operations' performance. The company's SCI was calculated by aggregating the performance of the main five SC performance measurement 
categories (RL, RS, AG, CO and AM). As illustrated in table 1, the company's SCI for period 1 was 0.56 revealing that the company's SC performance in this period was good on average (see equation 1).

\begin{tabular}{|l|l|l|l|l|}
\hline \multirow{2}{*}{ Measure } & \multicolumn{3}{|l}{ SCI } & \multirow{2}{*}{ Assessment rate } \\
\cline { 2 - 4 } & R & W & WR & \\
\hline RL & 0.72 & $20 \%$ & 0.143 & Very good (VG) \\
\hline RS & 0.62 & $20 \%$ & 0.123 & VG \\
\hline AG & 0.64 & $20 \%$ & 0.127 & VG \\
\hline CO & 0.29 & $20 \%$ & 0.059 & Poor (P) \\
\hline AM & 0.53 & $20 \%$ & 0.105 & Good (G) \\
\hline SUM & 2.8 & $100 \%$ & 0.557 & G \\
\hline
\end{tabular}

Table 1: SCI for period 1

$\mathrm{SC}$ index $(\mathrm{SCI})=\frac{\sum R}{N}=\frac{2.8}{5}=0.56$

where $\mathrm{N}$ represents the number of the main SC performance measures.

4.2 Evaluating the company's current financial performance and determining the priorities of financial performance factors

A negative return on asset ratio was registered by the company. The analysis revealed that the company had a good Total Asset Turnover compared to the industrial average, while the company's Net Profit Margin was below the industry average which indicated that the company had a problem in generating profit from its sales. Structured interviews were conducted with a group of decision makers at the strategic level in order to assign the priorities of the financial performance factors - with respect to financial results- using the pair-wise questionnaire scale. The priority weight given to the profitability factor was $84.5 \%$ compared to only $15.5 \%$ assigned to the efficiency factor. 


\subsection{Determining the relative weights of the five main SC} performance measures with respect to the financial performance priorities

Following the procedures developed by Elgazzar et al. (2012a), the group of decision makers was asked to rank the five main SC performance measures priority with regard to each financial performance factor. Structured interviews were conducted. Then, using the Dempster Shafer/Analytical Hierarchy Processes (DS/AHP) method the relative importance weights of the five main SC performance measures were calculated and ranked.

\begin{tabular}{|c|c|c|c|c|}
\hline Subsets & SUMm1(P)M2(E) & $\begin{array}{c}\mathbf{m}_{\text {sc performance }} \\
\text { measures }\end{array}$ & Weight(W) & Priority \\
\hline RL & 0.074417 & 0.122968 & $12 \%$ & 3 \\
\hline RS & 0.074417 & 0.122968 & $12 \%$ & 3 \\
\hline AG & $\mathbf{0 . 1 5 0 3 8 4}$ & $\mathbf{0 . 2 4 8 4 9 6}$ & $\mathbf{2 5 \%}$ & $\mathbf{2}$ \\
\hline CO & $\mathbf{0 . 1 8 5 8 6 4}$ & $\mathbf{0 . 3 0 7 1 2 3}$ & $\mathbf{3 1 \%}$ & $\mathbf{1}$ \\
\hline AM & 0.045707 & 0.075526 & $8 \%$ & 4 \\
\hline$\theta$ & 0.074386 & 0.122917 & $12 \%$ & \\
\hline
\end{tabular}

Table 2: The relative importance weights of the SC performance measures

As illustrated in table 2, $\mathrm{CO}$ and $\mathrm{AG}$ presented the most important SC performance measurement categories to focus on for the purpose of aligning with the company's short-term strategic financial priorities. Also, table 2 indicates an ignorance factor $(\theta)$ equal to 0.12 , which reflects the influence weight of the other unknown or uncontrollable factors that may impact the company's financial performance.

\subsection{Evaluating the efficiency and the effectiveness of current SC strategy}

As illustrated in table 3, the SCFLI for period 1 was 0.514 revealing the good contribution on average of SC operations' 
performance in enhancing the overall financial performance (see equation 2).

\begin{tabular}{|c|c|c|c|c|c|c|c|}
\hline \multirow{2}{*}{$\begin{array}{c}\text { Measu } \\
\text { re }\end{array}$} & \multicolumn{3}{|c|}{ SCI } & \multicolumn{3}{|c|}{ SCFLI } & \multirow{2}{*}{$\begin{array}{l}\text { Asses } \\
\text { smen } \\
\text { t rate }\end{array}$} \\
\hline & $\mathrm{R}$ & W & WR & $\mathrm{R}$ & $\mathrm{W}$ & WR & \\
\hline RL & 0.72 & $20 \%$ & 0.143 & 0.72 & $12 \%$ & 0.086 & $\mathrm{VG}$ \\
\hline $\mathrm{RS}$ & 0.62 & $20 \%$ & 0.123 & 0.62 & $12 \%$ & 0.074 & $\mathrm{VG}$ \\
\hline $\mathrm{AG}$ & 0.64 & $20 \%$ & 0.127 & 0.64 & $25 \%$ & 0.159 & $\mathrm{VG}$ \\
\hline $\mathrm{CO}$ & 0.29 & $20 \%$ & 0.059 & 0.29 & $31 \%$ & 0.091 & $\mathrm{P}$ \\
\hline $\mathrm{AM}$ & 0.53 & $20 \%$ & 0.105 & 0.53 & $8 \%$ & 0.042 & G \\
\hline SUM & 2.8 & $100 \%$ & 0.557 & 2.8 & $88 \%$ & 0.452 & $\mathrm{G}$ \\
\hline
\end{tabular}

Table 3: SCFLI for period 1

Supply chain financial link index (SCFLI) $=\frac{\sum W R}{\sum W}=\frac{0.452}{0.88}=0.514$

Based on the previous results, the company's short-term strategic financial objective was improving its profitability especially through managing its costs and this consequently lead to assigning the highest priority weight at the top level of the SCOR hierarchy to cost measures. Accordingly, the appropriate scenario to apply was Scenario One (managing SC costs) through formulating SC strategy aimed at enhancing the processes to which cost performance measures correspond. Finally, the subsequent objectives and action plans required to implement this strategy were identified. 


\subsection{Formulating new SC strategy based on the company's short-term strategic financial priorities}

\begin{tabular}{|c|c|c|c|c|c|c|c|}
\hline $\begin{array}{c}\text { Supply Chain Cost } \\
\text { measures }\end{array}$ & Min & Max & W & $\begin{array}{c}\text { Period } \\
\mathbf{1} \\
\text { perfor } \\
\text { mance }\end{array}$ & $\begin{array}{c}\text { Assess } \\
\text { m-ent } \\
\text { Rate }\end{array}$ & R & WR \\
\hline SCM Cost & 0.2 & 1 & 0.33 & - & P & 0.26 & 0.084 \\
\hline Cost of Goods Sold & 0.2 & 1 & 0.67 & & P & 0.31 & 0.209 \\
\hline Freight expense & 0.17 & 0.11 & 0.65 & 0.17 & VP & 0.2 & 0.13 \\
\hline Marketing expense & 0.08 & 0.04 & 0.07 & 0.08 & VP & 0.2 & 0.014 \\
\hline Sales expense & 0.2 & 0.15 & 0.21 & 0.21 & VP & 0.2 & 0.042 \\
\hline Administrative expense & 0.02 & 0.01 & 0.07 & 0.01 & E & 1 & 0.07 \\
\hline Cost to Make & 0.2 & 1 & & & - & & \\
\hline Material Cost & 0.75 & 0.54 & 0.56 & 0.67 & P & 0.4 & 0.224 \\
\hline Labour Cost & 0.15 & 0.09 & 0.15 & 0.14 & VP & 0.2 & 0.03 \\
\hline Indirect Costs & 0.25 & 0.14 & 0.29 & 0.19 & VP & 0.2 & 0.058 \\
\hline Table $4:$ The & & & & & & \\
\hline
\end{tabular}

Table 4: The aggregated performance of the company's SC cost measures

Table 4 shows the analysis of the performance of SC cost measures; the highest priority was assigned to SC processes to which the freight expense measure corresponds. Managing freight expense could highly impact SC cost performance since it had a very poor (VP) performance and the highest relative importance weight. The second priority was given to Material cost as it had a poor ( $\mathrm{P})$ performance and the highest relative importance weight compared to other cost to make measures. The third priority was assigned to direct Sales expense as it had a very poor performance and a relatively high importance weight. The fourth priority was managing SC processes that impact Indirect costs related to making product, while a lesser priority was assigned to Labour cost and direct marketing expense. 


\subsection{Evaluating the contribution of the new SC strategy in achieving the company's short-term financial strategic objectives}

The authors assumed that the suggested strategy would be applied to demonstrate how improving the relevant SC operations could influence the outcome in terms of the company's financial performance after one financial year under three different conditions (optimistic, normal and pessimistic).

Considering an optimistic assumption that the company would carry out the proposed strategy in full and all objectives would be accomplished, SC total cost would decrease by $28.8 \%$ between period 1 and period 2. As illustrated in table 4 , the changes in SC costs would impact the performance of the related SC performance measures. SC cost measures and some of the SC asset management measures would be affected positively by decreasing SC costs resulting in improvement in the overall SC performance assuming that all other variables would not change and remain constant. As a result, SCI for the end of period 2 would increase to be 0.717 revealing very good SC operations' performance for this period. In addition, managing SC costs would impact financial performance components (revenue, cost and assets). The company's total costs would be affected directly, while revenue and assets would be affected indirectly through increasing Net Income and efficiency of asset management. The company's SCFLI (period 2) would increase by approximately 26 percentage points and by $50 \%$ compared to (period 1) revealing improvement in the efficiency and the effectiveness of SC strategy in connecting to the company's short-term strategic financial objectives (see table 4).

Table 5 shows how the results would change if the proposed strategy was partially undertaken. Another two conditions are assumed (normal and pessimistic conditions). The normal condition assumes that only the first four objectives would be 
accomplished (reducing freight expense, reducing direct material cost, reducing direct sales expense and reducing labour cost). The pessimistic condition assumes that only the first two objectives would be accomplished (reducing freight expense and reducing direct material cost).

\begin{tabular}{|c|c|c|c|c|}
\hline \multirow[b]{2}{*}{$\frac{\text { Supply Chain Cost }}{\underline{\text { measures }}}$} & \multirow[b]{2}{*}{ Period 1} & \multicolumn{3}{|c|}{ For period 2} \\
\hline & & $\begin{array}{c}\text { Optimistic } \\
\text { condition }\end{array}$ & $\begin{array}{c}\text { Normal } \\
\text { condition }\end{array}$ & $\begin{array}{l}\text { Pessimistic } \\
\text { condition }\end{array}$ \\
\hline $\begin{array}{l}\text { Freight expense (\% of total } \\
\text { cost) }\end{array}$ & $\% 17$ & $10.8 \%$ & $10.8 \%$ & $10.8 \%$ \\
\hline $\begin{array}{l}\text { Direct marketing expense } \\
\quad(\% \text { of total cost })\end{array}$ & $\% 8$ & $3.6 \%$ & $8 \%$ & $8 \%$ \\
\hline $\begin{array}{c}\text { Direct sales expense (\% of } \\
\text { total cost) }\end{array}$ & $\% 21$ & $15.3 \%$ & $15.3 \%$ & $21 \%$ \\
\hline $\begin{array}{l}\text { Administrative expense (\% } \\
\text { of total cost) }\end{array}$ & $\% 1$ & $1 \%$ & $1 \%$ & $1 \%$ \\
\hline $\begin{array}{l}\text { Material Cost (\% of total } \\
\text { manufacturing cost) }\end{array}$ & $\% 67$ & $54 \%$ & $54 \%$ & $54 \%$ \\
\hline $\begin{array}{l}\text { Labour Cost }(\% \text { of total } \\
\text { manufacturing cost })\end{array}$ & $\% 14$ & $9 \%$ & $9 \%$ & $14 \%$ \\
\hline $\begin{array}{l}\text { Indirect Costs Related To } \\
\text { Making Product (\% of total } \\
\text { manufacturing cost) }\end{array}$ & $\% 19$ & $13.5 \%$ & $19 \%$ & $19 \%$ \\
\hline \multirow{2}{*}{$\frac{\text { Supply Chain Asset }}{\underline{\text { Management }}}$} & \multirow[b]{2}{*}{ Period 1} & \multicolumn{3}{|c|}{ For period 2} \\
\hline & & $\begin{array}{l}\text { Optimistic } \\
\text { condition }\end{array}$ & $\begin{array}{c}\text { Normal } \\
\text { condition }\end{array}$ & $\begin{array}{l}\text { Pessimistic } \\
\text { condition }\end{array}$ \\
\hline Return on working capital & $-1 \%$ & $5 \%$ & $3.7 \%$ & $1.8 \%$ \\
\hline Return on SC Fixed Assets & $\%-6$ & $31 \%$ & $22 \%$ & $11 \%$ \\
\hline Return on SC total Assets & $-3.42 \%$ & $18 \%$ & $12.6 \%$ & $6.3 \%$ \\
\hline \multirow[b]{2}{*}{$\begin{array}{c}\text { Supply chain's } \\
\text { performance indices }\end{array}$} & \multirow[b]{2}{*}{ Period 1} & \multicolumn{3}{|c|}{ For period 2} \\
\hline & & $\begin{array}{c}\text { Optimistic } \\
\text { condition }\end{array}$ & $\begin{array}{c}\text { Normal } \\
\text { condition }\end{array}$ & $\begin{array}{l}\text { Pessimistic } \\
\text { condition }\end{array}$ \\
\hline SCI & 0.56 & 0.717 & 0.68 & 0.64 \\
\hline SCFLI & 0.514 & 0.772 & 0.71 & 0.656 \\
\hline
\end{tabular}

Table 5: The performance before and after applying the suggested SC strategy 
Under the normal condition, SC total cost would decrease by $21.8 \%$ from period 1 to period 2, while it would decrease by $13.2 \%$ under the pessimistic condition. The results under both condition show improvement in SC performance as well as financial performance. SCI would improve to be 0.68 in the normal condition and 0.64 in the pessimistic condition revealing improvement in the company's SC operations' performance under both conditions. Also, the SCFLI would increase to reach 0.71 under the normal conditions and 0.656 under the pessimistic conditions which reflects the improvement in the efficiency and the effectiveness of SC strategy in connecting to the company's short-term strategic financial objectives. Many other conditions could arise, however, as shown in the previous three assumed conditions, any improvement in the SC operations' performance will lead to better SCM, and consequently enhance the company's overall financial performance.

\section{CONCLUSION AND FURTHER WORK}

The research study makes an original contribution in the direction of linking SC strategy to a company's financial strategy through focusing on studying the relationships between SCM practices and financial performance improvements. An integrated supply chain performance measurement system was created and implemented to demonstrate and utilise the relationship between SC performance metrics and financial performance metrics. A scenario analysis approach was undertaken using five main alternative scenarios in order to explore how this procedure could be applied with regard to various possible financial results. A case study of a manufacturing company was conducted and analysed to illustrate the applicability of the research procedures.

Future research should consider collecting data for more than one financial year so as to investigate the impact of 
implementing the suggested SC strategy on improving SC operations' performance and enhancing the overall financial performance. In addition, further work should investigate and compare the results from several companies in different manufacturing sectors in different locations. Since the SCOR model provides standard descriptions of SC processes and standard metrics to measure the performance, the research procedure can be generalised to be applicable in any manufacturing company from any other sector. 


\section{REFERENCES}

Basu, R., 2001. New criteria of performance management: A transition from enterprise to collaborative supply chain. Measuring Business Excellence 5, 7-12.

Beynon, M., Curry, B., Morgan, P., 2000. The Dempster-Shafer theory of evidence: an alternative approach to multicriteria decision modelling. The International Journal of Management Science 28, 37-50.

Cagnazzo, L., Taticchi, P., Brun, A., 2010. The role of performance measurement systems to support quality improvement initiatives at supply chain level. International Journal of Productivity and Performance Management 59, 163185.

Camerinelli, E., Cantu, A., 2006. Measuring the Value of the Supply Chain: A Framework. Supply Chain Practice 8, 40-59. Elgazzar, S., Tipi, N.S., Hubbard, N.J., Leach, D.Z., 2010. Incorporating fuzzy AHP in SCOR model for measuring supply chain operations performance: a case study of an Egyptian natural bottled water company. In: Proceedings from: The $15^{\text {th }}$ Annual Logistics Research Network Conference. Harrogate, UK.

Elgazzar, S., Tipi, N.S., Hubbard, N.J., Leach, D.Z., 2011. A SW application system for measuring supply chain operations' performance using SCOR FAHP technique. In: Proceedings from: The 2011 International Conference on Business and Economics Research. Cairo, Egypt.

Elgazzar, S., Tipi, N.S., Hubbard, N.J., Leach, D.Z., 2012a. Linking supply chain processes' performance to a company's financial strategic objectives. European Journal of Operational Research223, 276-289.

Elgazzar, S., Tipi, N.S., Hubbard, N.J., Leach, D.Z., $2012 b$. Linking SCM strategy to financial performance: a scenario 
analysis approach. In: Proceedings from: The $17^{\text {th }}$ Annual Logistics Research Network Conference, Cranfield, UK.

Elgazzar, S. 2013. Enhancing the company's financial performance through managing the performance of supply chain operations: a case study of an Egyptian manufacturing company. PhD thesis, University of Huddersfield, UK.

Gunasekaran, A., Patel, C., McGaughey, R.E., 2004. A framework for supply chain performance measurement, International Journal of Production Economics87, 333-347.

Kremers, L., 2010. The Link between Supply Chain and Finance. Supply Chain Asia, 22-25.

Li, S., Ragu-Nathanb, B., Ragu-Nathanb, T. S., Rao, S.S., 2006. The impact of supply chain management practices on competitive advantage and organizational performance. Omega-International Journal of Management Science 34, 107-124.

Mitroff, I.I., Betz, F., Pondy, L.R., Sagasti, F., 1974. On managing science in the systems age: two schemas for the study of science as a whole systems phenomenon. Interfaces 4, 46-58.

Prajogo, D., Oke, A., Olhager,J., 2016. Supply chain processes: Linking supply logistics integration, supply performance, lean processes and competitive performance. International Journal of Operations \& Production Management 36, 220-238.

Toyli, J., Häkkinen, L., Ojala, L., Naula, T., 2008. Logistics and financial performance, An analysis of 424 Finnish small and medium-sized enterprises. International Journal of Physical Distribution \& Logistics Management38, 57-80.

Wagner, S.M., Grosse-Ruyken, P.T., Erhun, F., 2012. The Link between Supply Chain Fit and Financial Performance of the Firm. Journal of Operations Management 30, 340-353.

Wisner, P., 2011. Linking Supply Chain Performance to a Firm's

Financial Performance. Supply Chain Management Review. 
Woei, L.S., 2008. Supply chain performance and financial success of selected companies on bursa Malaysia. Masters dissertation, University of Malaya, Malaysia.

Zuriekat, M., Salameh, R., Alrawashdeh, S., 2011. Participation in Performance Measurement Systems and Level of Satisfaction. International Journal of Business and Social Science 2, 159-169. 
baabaker, et al. 